\title{
Isolating and Identifying the Atrazine-Degrading Strain Arthrobacter sp. LY-1 and Applying it for the Bioremediation of Atrazine-Contaminated Soil
}

\author{
Yangyang Li, Dong Liang, Junxue Sha, Jinbo Zhang, Jiguo Gao, \\ Haitao Li, Rongmei Liu* \\ College of Life Science, Northeast Agricultural University, Harbin, China
}

Received: 15 October 2017

Accepted: 4 March 2018

\begin{abstract}
Atrazine is a widely used herbicide, and because of its potential to seriously pollute soil and water resources, has attracted widespread attention. In this study, the bacterial strain LY-1 was isolated and identified as the species Arthrobacter. At present, there are many different atrazine-degrading bacteria that have been screened out, including Arthrobacter sp., Pseudomonas sp., and Shewanella sp. However, previous reports only studied their degradation effects and soil remediation capabilities under optimum conditions and there were few studies performed which took into account a wider array of environmental circumstances. This study investigated the degradation effects of LY-1, as well as its capacity for soil remediation, under various conditions. The strain had broad optimum ranges of temperature and $\mathrm{pH}$ and the additional carbon and nitrogen sources did not decrease the atrazine degradation rate. In addition, the soil remediation tests indicated that the strain LY-1 might be a good candidate for bioremediation of atrazine-polluted soil.
\end{abstract}

Keywords: atrazine, Arthrobacter sp., atrazine-degrading genes, biodegradation, bioremediation

\section{Introduction}

The s-triazine chemical herbicide atrazine (2-chloro4-ethylamino-6-isopropylamino-1, 3, 5-triazine) is widely used to control annual grass and broadleaf weeds in the agriculture of sugarcane (Saccharum officinarum), sorghum (Sorghum spp.), maize (Zea mays), and other crops [1]. Because of its long half-life and high mobility in soil, atrazine and its derivatives have been detected in soils, and surface and groundwater [2]. Moreover, it

*e-mail: liurongmei@neau.edu.cn also interferes with the endocrine systems of humans and animals and its use affects ecosystems and human health [3]. In recent years, bioremediation methods have become an ideal solution to the problem of atrazine contamination because of their low cost, effectiveness, and lack of secondary pollution [4].

Currently, a number of bacteria with different atrazine degradation efficiencies and growth characteristics have been isolated. These strains include Shewanella sp. YJY4, Arthrobacter sp. TC1, Pseudomonas sp. ADP, Citricoccus sp. TT3, Rhodococcus sp. $\mathrm{BCH} 2$, and Bacillus subtilis HB-6 [5-9]. Of all presently known strains, the degradation 
pathways of Pseudomonas sp. ADP and Arthrobacter sp. TC1 are studied most clearly. Strain ADP contains the degradation genes $a t z A, a t z B, a t z C$, atzD, atzE, and $a t z F$, which can completely degrade atrazine [10]. Stain TC1 contains the degradation genes $\operatorname{trzN}$, atzB, and $a t z C$, which can transform atrazine into non-toxic cyanuric acid. The atrazine-degrading genes $\operatorname{trz} N$, atzA, $t r z D$, and $a t z D$ have the same function respectively [11].

In this study, a high-efficiency atrazine degrader, bacterial strain LY-1, was isolated from a cornfield where atrazine had been used for a long time. The identification of the strain, its degradation genes, the influence of environmental factors, and soil remediation ability were studied. Environmental factors have a significant effect on atrazine degradation [12]. These factors include atrazine concentration, temperature, $\mathrm{pH}$, carbon, and nitrogen sources. The objective of this study was to provide a highly efficient strain resource for the bioremediation of atrazine-contaminated soil.

\section{Materials and Methods}

\section{Soil Samples and Reagents}

Experimental soil was sampled from the surface layer of the cornfield where atrazine was used for a long time $(0-10 \mathrm{~cm})$. The area is located northwest of Heilongjiang Province, China. Soil samples were treated in a $2.0 \mathrm{~mm}$ sieve and stored at $4^{\circ} \mathrm{C}$.

Atrazine of $99 \%$ purity was used to characterize the atrazine-degrading bacteria, which were purchased from Shanghai KALANG Technology Ltd. The 99\% pure cyanuric acid was purchased from WEIFANG KAIRUI Chemical Co., Ltd. All other chemicals in the experiment were analytical or HPLC-grade reagents.

The liquid enrichment medium consisted of mineral salts medium (MSM), $3 \mathrm{~g} \cdot \mathrm{l}^{-1}$ glucose, and $100 \mathrm{mg} \cdot \mathrm{l}^{-1}$ atrazine as the carbon and nitrogen sources, respectively. The MSM contained $0.5 \mathrm{~g} \cdot \mathrm{l}^{-1}$ of $\mathrm{KH}_{2} \mathrm{PO}_{4}$, $3.0 \mathrm{~g} \cdot \mathrm{l}^{-1}$ of $\mathrm{K}_{2} \mathrm{HPO}_{4}, 0.2 \mathrm{~g} \cdot \mathrm{l}^{-1}$ of $\mathrm{MgSO}_{4} \cdot 7 \mathrm{H}_{2} \mathrm{O}, 0.5 \mathrm{~g} \cdot \mathrm{l}^{-1}$ of $\mathrm{NaCl}$, and $1 \mathrm{ml} \cdot \mathrm{l}^{-1}$ of trace element concentrate solution. Trace element concentrate solution had the following composition: $\mathrm{FeSO}_{4} \cdot 7 \mathrm{H}_{2} \mathrm{O}, 1 \mathrm{~g} \cdot \mathrm{l}^{-1} ; \mathrm{ZnSO}_{4} \cdot 7 \mathrm{H}_{2} \mathrm{O}$, $5 \mathrm{~g} \cdot \mathrm{l}^{-1} ; \mathrm{CuSO}_{4} \cdot 5 \mathrm{H}_{2} \mathrm{O}, 0.4 \mathrm{~g} \cdot \mathrm{l}^{-1} ; \mathrm{MnSO}_{4} \cdot \mathrm{H}_{2} \mathrm{O}, 1 \mathrm{~g} \cdot \mathrm{l}^{-1}$; EDTA, $2.5 \mathrm{~g} \cdot \mathrm{l}^{-1} ; \mathrm{Na}_{2} \mathrm{MoO}_{4} \cdot 2 \mathrm{H}_{2} \mathrm{O}, 0.25 \mathrm{~g} \cdot \mathrm{l}^{-1}$, and $\mathrm{Na}_{2} \mathrm{~B}_{4} \mathrm{O}_{7} \cdot 10 \mathrm{H}_{2} \mathrm{O}$, $0.2 \mathrm{~g} \cdot \mathrm{l}^{-1}$. The solid medium was added to $13 \mathrm{~g} \cdot \mathrm{l}^{-1}$ of agar. All of the above cultures were regulated to $\mathrm{pH} 7.0$ and sterilized at $121^{\circ} \mathrm{C}$ for $30 \mathrm{~min}$.

\section{Enrichment and Isolation}

The five-gram soil specimens were transferred to $250 \mathrm{ml}$ flasks containing $100 \mathrm{ml}$ of MSM, to which $3 \mathrm{~g} \cdot \mathrm{l}^{-1}$ glucose and $100 \mathrm{mg} \cdot \mathrm{l}^{-1}$ atrazine were added. These specimens were cultured on a $160 \mathrm{r} \cdot \mathrm{min}^{-1}$ shaker for 7 days and the temperature was kept at $30^{\circ} \mathrm{C}$. And then enrichment culture was inoculated into the new medium according to the inoculation amount of $5 \%$.
The concentration of atrazine in the new medium was $200 \mathrm{mg} \cdot \mathrm{l}^{-1}$ and this process was repeated until the concentration of atrazine reached $500 \mathrm{mg} \cdot \mathrm{l}^{-1}$. Eventually, the medium was diluted and placed onto the agar plates that contained $100 \mathrm{mg} \cdot \mathrm{l}^{-1}$ of atrazine. LY-1 was used for further studies because it demonstrated a high capacity for degrading atrazine.

\section{Identifying Atrazine-Degrading Strain LY-1}

The identification of strain LY-1 was accomplished by observing the results of biochemical reactions and 16S rDNA sequencing. The total DNA of the strain was used as a template for amplification. 27F (5'-AGAGTTTGATCCTGGCTCAG-3') and 1492R (5'-TACGGCTACCTTGTTACGACTT-3') were used as forward and reverse primers, respectively [13]. The PCR conditions were as follows: $94^{\circ} \mathrm{C}$ for $5 \mathrm{~min}$ followed by 30 cycles of $94^{\circ} \mathrm{C}$ for $1 \mathrm{~min}, 54^{\circ} \mathrm{C}$ for $1 \mathrm{~min}$, and $72^{\circ} \mathrm{C}$ for $2 \mathrm{~min}$, with a final extension of $10 \mathrm{~min}$ at $72^{\circ} \mathrm{C}$. The products of PCR were divided on a $1.2 \%$ agarose gel electrophoresis. The resulting DNA fragments were purified through AxyPrep DNA gel extraction kit (Axygen), and then cloned into the pMD19-T vector (TaKaRa, China). The vector was transformed into Escherichia coli strain DH5a. Genetic sequencing was completed by Jilin Comate Bioscience Co., Ltd., and the results were compared using the Blast program in the NCBI GenBank nucleotide database. MEGA version 6.0 was used to construct the phylogenetic tree.

\section{PCR Detection of Atrazine-Degrading Genes}

Currently known atrazine-degrading genes included $a t z A, a t z B, a t z C, a t z D, a t z E, a t z F, \operatorname{trz} D$, and $\operatorname{trz} N$ [14]. The size, sequences, and anneal temperature of these primers were shown in Table 1. The total chromosomal DNA of strain LY-I was used as a template to amplify these genes. The conditions of PCR were as follows: at $94^{\circ} \mathrm{C}$ preheated $5 \mathrm{~min}, 30$ cycles of denaturation at $94^{\circ} \mathrm{C}$ for $1 \mathrm{~min}$, annealed at $58,64,54,60,52,55,56$, and $53^{\circ} \mathrm{C}$ for $1 \mathrm{~min}$ to $a t z A, a t z B, a t z C, a t z D, a t z E, a t z F$ genes and $\operatorname{trz} N, \operatorname{trz} D$ genes, respectively, extension at $72^{\circ} \mathrm{C}$ for $90 \mathrm{~s}$, and final extension at $72^{\circ} \mathrm{C}$ for $10 \mathrm{~min}$. The research team performed sequencing and sequence analysis according to the above method.

\section{Growth and Biodegradation Capacity of Strain LY-1 and Influential Factors}

In order to determine the growth curve of the strain, either atrazine or cyanuric acid $\left(100 \mathrm{mg} \cdot \mathrm{l}^{-1}\right)$ was added to the $100 \mathrm{ml}$ MSM medium as the nitrogen source, and glucose $\left(3 \mathrm{~g} \cdot \mathrm{l}^{-1}\right)$ was added as the carbon source. The strain LY-1 used for inoculation was incubated at $30^{\circ} \mathrm{C}$ for $12 \mathrm{~h}$ and centrifuged at $7000 \mathrm{r} \cdot \mathrm{min}^{-1}$, and it was suspended with sterile water to 0.1 at $600 \mathrm{~nm}\left(\mathrm{OD}_{600}\right)$. One milliliter of treated bacteria was inoculated into the medium and these treatments were incubated in 
Table 1. PCR primers, expected product sizes, and annealing temperatures in the amplification of atrazine-degrading genes.

\begin{tabular}{|c|c|c|c|c|}
\hline Gene & Primer & Gene size $(\mathrm{kb})$ & Sequence $\left(5^{\prime} \rightarrow 3^{\prime}\right)$ & Annealing $\left({ }^{\circ} \mathrm{C}\right)$ \\
\hline \multirow{2}{*}{$a t z A$} & $\operatorname{atz} A-1$ & \multirow{2}{*}{530} & CCATGTGAACCAGATCCT & \multirow{2}{*}{58} \\
\hline & $a t z A-2$ & & TGAAGCGTCCACATTACC & \\
\hline \multirow{2}{*}{$a t z B$} & $a t z B-1$ & \multirow{2}{*}{510} & TCACCGGGGATGTCGCGGGC & \multirow{2}{*}{64} \\
\hline & $a t z B-2$ & & CTCTCCCGCATGGCATCGGG & \\
\hline \multirow{2}{*}{$a t z C$} & $a t z C-1$ & \multirow{2}{*}{610} & GCTCACATGCAGGTACTCCA & \multirow{2}{*}{54} \\
\hline & $a t z C-2$ & & GTACCATATCACCGTTTGCCA & \\
\hline \multirow{2}{*}{$a t z D$} & $a t z D-1$ & \multirow{2}{*}{1050} & GGAGACATCATATGTATCACATCGACGTTTTC & \multirow{2}{*}{60} \\
\hline & $a t z D-2$ & & CCAATAAGCTTAGCGCGGGCAATGACTGCA & \\
\hline \multirow{2}{*}{$a t z E$} & atzE-1 & \multirow{2}{*}{990} & TACGCGGTAAAGAATCTGTT & \multirow{2}{*}{52} \\
\hline & $a t z E-2$ & & GGAGACCGGCTGAGTGAGA & \\
\hline \multirow{2}{*}{$a t z F$} & $\operatorname{arzF-1}$ & \multirow{2}{*}{910} & CGATCGGAAAAACGAACCTC & \multirow{2}{*}{55} \\
\hline & $a t z F-2$ & & CGATCGCCCCATCTTCGAAC & \\
\hline \multirow{2}{*}{$\operatorname{trz} D$} & $\operatorname{trz} D-1$ & \multirow{2}{*}{760} & CCTCGCGTTCAAGGTCTACT & \multirow{2}{*}{53} \\
\hline & $\operatorname{trz} D-2$ & & TCGAAGCGATAACTGCATTG & \\
\hline \multirow{2}{*}{$\operatorname{trz} N$} & $\operatorname{trz} N-1$ & \multirow{2}{*}{1360} & ATGATCCTGATCCGCGGACTGA & \multirow[t]{2}{*}{56} \\
\hline & $t r z N-2$ & & CTACAAGTTCTTGGGAATGAGTG & \\
\hline
\end{tabular}

a $160 \mathrm{r} \cdot \mathrm{min}^{-1}$ shaker with a culture temperature of $30^{\circ} \mathrm{C}$. Samples were taken every $4 \mathrm{~h}$, until $48 \mathrm{~h}$ worth of samples were measured. The growth of the strain was determined by measuring its absorbance at $600 \mathrm{~nm}$ using a spectrophotometer (U-2910; HITACHI, Japan). The effects of atrazine concentration, temperature, $\mathrm{pH}$, carbon, and nitrogen sources on the growth of the strain were also measured. All experiments were repeated three times to ensure accuracy.

When the effect of atrazine concentration on the growth of the strain was determined, the concentration was adjusted to $50,100,200,500$ and $1000 \mathrm{mg} \cdot l^{-1}$, respectively. The temperature was adjusted to $5,10,15$, $20,25,30,35$, and $40^{\circ} \mathrm{C}$ and the $\mathrm{pH}$ was adjusted to 3 , $4,5,6,7,8,9,10$ and 11 , respectively. The concentration of atrazine in these cultures was $100 \mathrm{mg} \cdot \mathrm{l}^{-1}$. The effects of the carbon and nitrogen sources on the growth of strain were studied by referring to previous methods [15]. The methods for determining the effects of carbon sources on the growth of strain LY-1 were as follows: 1) $\operatorname{MSM}(100 \mathrm{ml})+100 \mathrm{mg} \cdot \mathrm{l}^{-1} \mathrm{KNO}_{3}+100 \mathrm{mg} \cdot \mathrm{l}^{-1}$ atrazine; 2) $\operatorname{MSM}(100 \mathrm{ml})+100 \mathrm{mg} \cdot \mathrm{l}^{-1} \mathrm{KNO}_{3}+3 \mathrm{~g} \cdot \mathrm{l}^{-1}$ glucose; 3) $\operatorname{MSM}(100 \mathrm{ml})+100 \mathrm{mg} \cdot \mathrm{l}^{-1} \mathrm{KNO}_{3}+3 \mathrm{~g} \cdot \mathrm{l}^{-1}$ sucrose; 4) $\operatorname{MSM}(100 \mathrm{ml})+100 \mathrm{mg} \cdot \mathrm{l}^{-1} \mathrm{KNO}_{3}+3 \mathrm{~g} \cdot \mathrm{l}^{-1}$ starch; and 5) MSM $(100 \mathrm{ml})+100 \mathrm{mg} \cdot \mathrm{l}^{-1} \mathrm{KNO}_{3}$. The last one is a control group which did not add a carbon source. The methods for determining the effects of additional nitrogen sources on the growth of strain LY-1 were as follows: 1) MSM (100ml) $+3 \mathrm{~g} \cdot \mathrm{l}^{-1} \mathrm{starch}+100 \mathrm{mg} \cdot \mathrm{l}^{-1}$ atrazine $+100 \mathrm{mg} \cdot \mathrm{l}^{-1}$ cyanuric acid; 2) MSM (100ml) $+3 \mathrm{~g} \cdot \mathrm{l}^{-1} \mathrm{starch}+100 \mathrm{mg} \cdot \mathrm{l}^{-1}$ atrazine $+100 \mathrm{mg} \cdot \mathrm{l}^{-1}$ urea;
3) $\operatorname{MSM}(100 \mathrm{ml})+3 \mathrm{~g} \cdot \mathrm{l}^{-1} \mathrm{starch}+100 \mathrm{mg} \cdot \mathrm{l}^{-1}$ atrazine $+100 \mathrm{mg} \cdot l^{-1} \mathrm{NH}_{4} \mathrm{Cl}$; 4) MSM $(100 \mathrm{ml})+3 \mathrm{~g} \cdot \mathrm{l}^{-1} \mathrm{starch}+$ $100 \mathrm{mg} \cdot \mathrm{l}^{-1}$ atrazine $+100 \mathrm{mg} \cdot \mathrm{l}^{-1} \mathrm{KNO}_{3}$; and 5) MSM $(100 \mathrm{ml})+3 \mathrm{~g} \cdot \mathrm{l}^{-1} \mathrm{starch}+100 \mathrm{mg} \cdot \mathrm{l}^{-1}$ atrazine. The last one is a control group, which did not add an additional nitrogen source. These treatment groups were incubated in a $160 \mathrm{r} \cdot \mathrm{min}^{-1}$ shaker for $48 \mathrm{~h}$, and the culture temperature was maintained at $30^{\circ} \mathrm{C}$. The growth of the strain was determined by measuring its absorbance at $600 \mathrm{~nm}$ using a spectrophotometer (U-2910; HITACHI, Japan).

The degradation capacity of atrazine was monitored using high-performance liquid chromatography (HPLC) analysis [16]. The concentrations of atrazine, as well as its temperature and $\mathrm{pH}$, were the same as those mentioned above, and the concentration of atrazine was $100 \mathrm{mg} \cdot \mathrm{l}^{-1}$. The methods for determining the effects of carbon sources on the biodegradation capacity of strain LY-1 were as follows: 1) MSM (100 ml) + $100 \mathrm{mg} \cdot \mathrm{l}^{-1}$ atrazine $+3 \mathrm{~g} \cdot \mathrm{l}^{-1}$ glucose; 2) MSM (100 $\mathrm{ml})+100 \mathrm{mg} \cdot \mathrm{l}^{-1}$ atrazine $+3 \mathrm{~g} \cdot \mathrm{l}^{-1}$ sucrose; 3) MSM $(100 \mathrm{ml})+100 \mathrm{mg} \cdot \mathrm{l}^{-1}$ atrazine $+3 \mathrm{~g} \cdot \mathrm{l}^{-1}$ starch; and 4) MSM $(100 \mathrm{ml})+100 \mathrm{mg} \cdot \mathrm{l}^{-1}$ atrazine The methods for determining the effects of nitrogen sources on the biodegradation capacity of strain LY-1 were as follows: 1) $\operatorname{MSM}(100 \mathrm{ml})+3 \mathrm{~g} \cdot \mathrm{l}^{-1} \mathrm{starch}+100 \mathrm{mg} \cdot \mathrm{l}^{-1}$ atrazine $+100 \mathrm{mg} \cdot \mathrm{l}^{-1}$ urea; 2) MSM $(100 \mathrm{ml})+3 \mathrm{~g} \cdot \mathrm{l}^{-1} \mathrm{starch}+$ $100 \mathrm{mg} \cdot l^{-1}$ atrazine $+100 \mathrm{mg} \cdot l^{-1} \mathrm{NH}_{4} \mathrm{Cl}$; 3) $\mathrm{MSM}$ $(100 \mathrm{ml})+3 \mathrm{~g} \cdot \mathrm{l}^{-1} \mathrm{starch}+100 \mathrm{mg} \cdot \mathrm{l}^{-1}$ atrazine + $100 \mathrm{mg} \cdot \mathrm{l}^{-1} \quad \mathrm{KNO}_{3}$; and 4) MSM (100 $\left.\mathrm{ml}\right) \quad+$ $3 \mathrm{~g} \cdot \mathrm{l}^{-1}$ starch $+100 \mathrm{mg} \cdot \mathrm{l}^{-1}$ atrazine. In the two 
experiments, control groups were set which did not add carbon and additional nitrogen sources. The atrazine concentration and cyanuric acid production were quantified by HPLC (Waters 600; Waters). The detection conditions for atrazine were as follows: the mobile phase was methanol: water $=80: 20$ (v:v), the flow rate was $1 \mathrm{ml} \cdot \mathrm{min}^{-1}$ and the UV detector was set to $216 \mathrm{~nm}$. For the detection of cyanuric acid [17], the flow rate was $0.8 \mathrm{ml} \cdot \mathrm{min}^{-1}\left(50 \mathrm{mM} \mathrm{K}_{2} \mathrm{HPO}_{4}\right.$ / methanol $=95: 5, \mathrm{v}: \mathrm{v})$, and the UV detector was set to $213 \mathrm{~nm}$. The injection volumes of all samples were $20 \mu 1$.

\section{Bioremediation of Atrazine-Contaminated Soil}

The soil was collected from the experimental farm of Northeast Agricultural University, where atrazine had never been used $(0-20 \mathrm{~cm})$. Soil samples were treated in a $2.0 \mathrm{~mm}$ sieve and sterilized at $121^{\circ} \mathrm{C}$ for $50 \mathrm{~min}$. Then, the soil was baked in an oven $\left(80^{\circ} \mathrm{C}\right)$ and stored at $4^{\circ} \mathrm{C}$ until used.

The atrazine was dissolved in methanol $\left(10^{4} \mathrm{mg} \cdot \mathrm{l}^{-1}\right)$. The soil was placed in a fume hood for $48 \mathrm{~h}$ until the methanol evaporated. The final concentration of atrazine in the soil was $100 \mathrm{mg} \cdot \mathrm{kg}^{-1} .200 \mathrm{~g}$ of contaminated soil was added to each pot. The strain LY-1 was resuspended with sterile water to a density of about $1 \times 10^{6}$ and $1 \times 10^{8}$ colony forming units (CFU) $\mathrm{ml}^{-1}$ (adjusted using a standard curve relating absorbance at $600 \mathrm{~nm}$ with plate count on MSM) [18]. Experimental treatments were used as follows: 1) contaminated soil $(200 \mathrm{~g})+$ strain LY-1(5 ml, $\left.1 \times 10^{6} \mathrm{CFU} \cdot \mathrm{ml}^{-1}\right)$; 2) contaminated soil (200 g) + strain LY-1(5 ml, $\left.1 \times 10^{8} \mathrm{CFU} \cdot \mathrm{ml}^{-1}\right)$; and 3) contaminated soil $(200 \mathrm{~g})+$ sterile water $(5 \mathrm{ml})$. Each treatment was performed in triplicate. During the test period, the soilwater content of each treatment was maintained at $20 \%$.
All treatments were placed at $25^{\circ} \mathrm{C}$ room temperature. On the 7 th and 14th days, $10 \mathrm{~g}$ of soil samples were weighed from each group to detect the concentration of residual atrazine.

Thirty milliliters of methanol was added to each weighed soil sample, which was agitated for $2 \mathrm{~h}$. The samples were placed for $24 \mathrm{~h}$ and then shaken for another hour. The treatments were centrifuged at $8000 \mathrm{r} \cdot \mathrm{min}^{-1}$ for $10 \mathrm{~min}$ and the supernatant was passed through a $0.22 \mu \mathrm{m}$ filter for the detection of HPLC. The detection conditions were the same as those mentioned above.

\section{Results and Discussion}

\section{Isolation and Identification of Strain LY-1}

The strain LY-1 was isolated from the experimental soil, which was a Gram-positive bacterium. The results of HPLC showed that the strain could degrade 99.5\% of the atrazine $\left(100 \mathrm{mg} \cdot \mathrm{l}^{-1}\right)$ within $48 \mathrm{~h}$. The $16 \mathrm{~S}$ rDNA amplification products were sequenced and the sequence was submitted to GenBank (under accession No. KX905053). The sequence had a high similarity with many Arthrobacter sp. strains (Fig. 1). According to its physiological and biochemical characteristics, together with the sequential analysis, the strain LY-1 was identified as Arthrobacter species. Arthrobacter species strains were often found in many contaminated areas, and many Arthrobacter species were isolated from agricultural soil and were capable of degrading atrazine [19]. These results showed that Arthrobacter sp. LY-1 might hold great potential for the bioremediation of atrazine-contaminated soil.

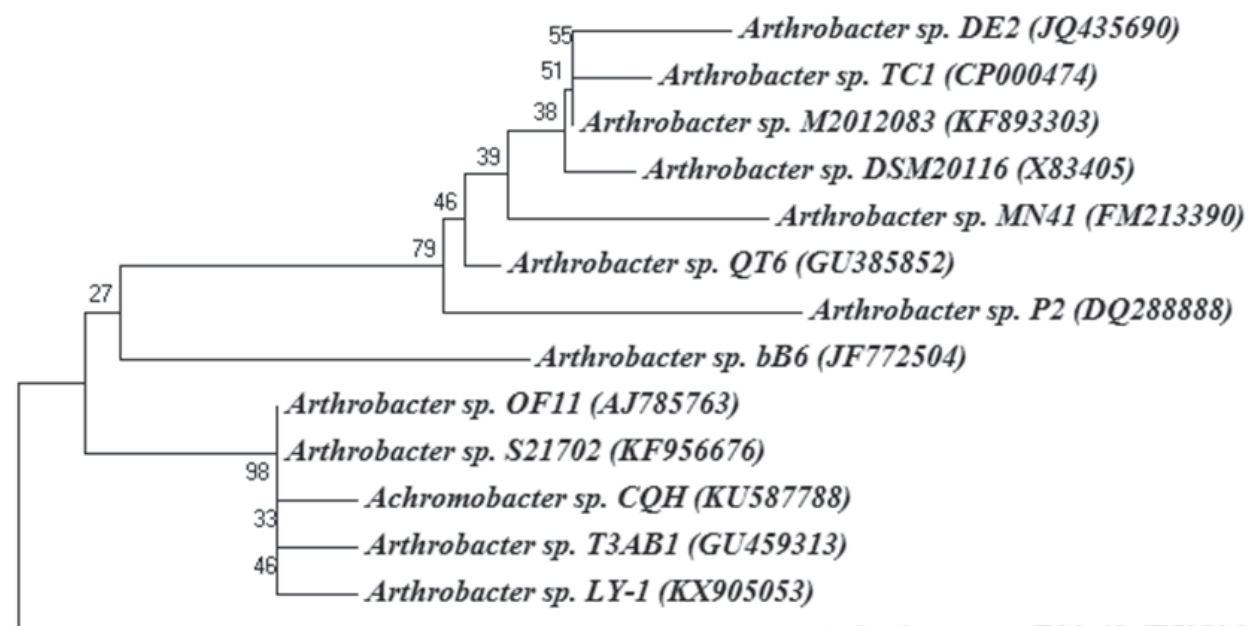

Arthrobacter sp. ES3-69 (KJ878641)

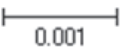

Fig. 1. Phylogenetic analysis of the 16S rDNA sequences of Arthrobacter sp. LY-1; numbers on the branch points represent bootstrap values from the neighborhood-joining analysis of 1,000 resampled data sets; the bar indicates $0.1 \%$ substitution per nucleotide position. 


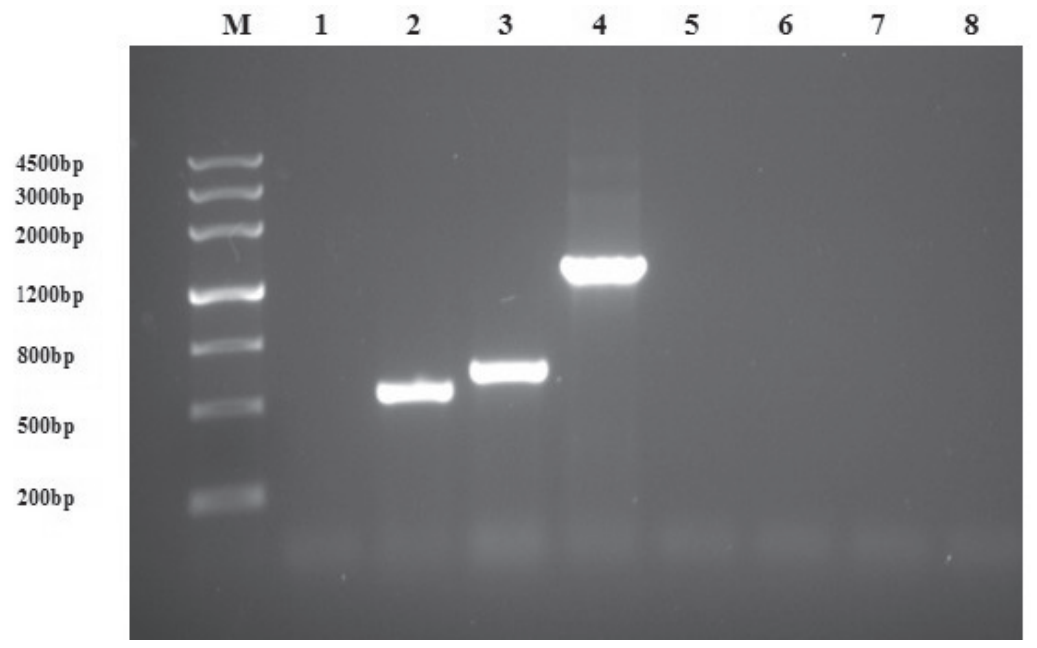

Fig. 2. Agarose gel electrophoresis (1.2\%) of PCR products of atrazine-degrading genes of strain LY-1; lanes 1 to 8 indicate the PCR amplification products for $a t z A, a t z B, a t z C, \operatorname{trz} N, a t z D, a t z E, a t z F$, and $\operatorname{trz} D$.

\section{PCR Detection of Atrazine-Degrading Genes in Strain LY-1}

The atrazine-degrading related genes were amplified by using the total DNA of the strain LY-1 as template. The products of $1370 \mathrm{bp} \operatorname{trzN}, 500 \mathrm{bp}$ atzB and $600 \mathrm{bp}$ $a t z C$ genes were obtained, as shown in Fig. 2, while the products of other genes were not obtained, including $a t z C, a t z D, a t z E, a t z F$, and $t r z D$. The conditions of PCR were adjusted repeatedly, but other atrazine-degrading genes were not amplified successfully. The results of sequence determination and comparison demonstrated that the nucleotide sequences of $\operatorname{trz} N$, atzB, and $a t z C$ from Arthrobacter sp. LY-1 showed 98\%, 99\%, and 100\% sequence similarity with those of Arthrobacter sp. TC1 (Genbank accession number CP000475). These all indicated that strain LY-1 contained $\operatorname{trz} N, \operatorname{atz} B$, and $a t z C$ genes.

A number of reported Arthrobacter species only contained $\operatorname{trz} N, \operatorname{atz} B$, and $a t z C$ genes, such as
Arthrobacter sp. DAT1, Arthrobacter sp. AK-YN10 and Arthrobacter sp. TC1 [20-22]. These Arthrobacter species could only degrade atrazine to cyanuric acid and it was supposed that the strain LY-1 could also degrade atrazine to non-toxic cyanuric acid.

\section{Growth and Degradation Characteristics of Strain LY-1}

The growth characteristics of strain LY-1 were measured in the medium in which the sole nitrogen sources were atrazine or cyanuric acid (Fig. 3a). When using atrazine as the sole nitrogen source, $\mathrm{OD}_{600}$ increased markedly and reached its maximum value at $44 \mathrm{~h}$, while within $12 \mathrm{~h}$ after inoculation the strain grew slowly, indicating that the strain has a certain period of adaptation. When cyanuric acid was used as the sole nitrogen source, the strain hardly grew. This illustrated that strain LY-1 could not utilize cyanuric acid as the sole nitrogen source to grow.
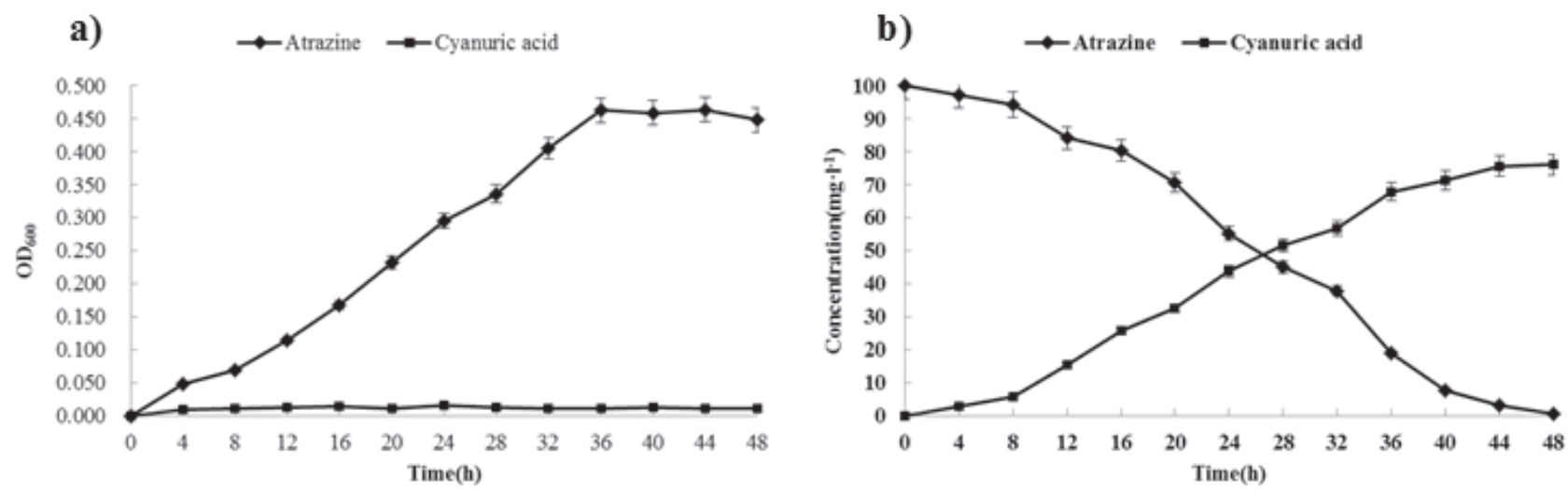

Fig. 3. a) Growth curve of strain LY-1 in MSM medium containing either atrazine or cyanuric acid $\left(100 \mathrm{mg} \cdot \mathrm{l}^{-1}\right)$ as the sole nitrogen source and b) Atrazine degradation curve containing atrazine $\left(100 \mathrm{mg} \cdot \mathrm{l}^{-1}\right)$ as the sole nitrogen source; the concentration of cyanuric acid was detected by HPLC in MSM medium. 
We also measured the degradation characteristics of strain LY-1 in the medium in which the sole nitrogen source was atrazine (Fig. 3b)). The strain LY-1 could degrade $99.5 \%$ of the atrazine (100 $\left.\mathrm{mg} \cdot \mathrm{l}^{-1}\right)$ within $48 \mathrm{~h}$. With the decrease of atrazine concentration, the concentration of cyanuric acid increased gradually.

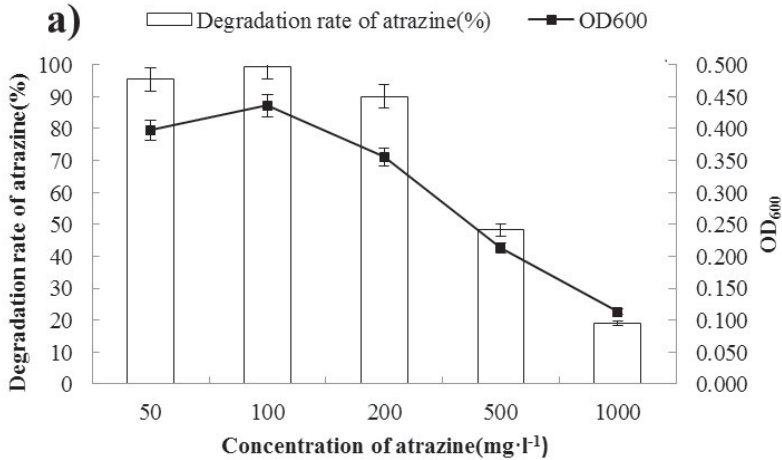

c) $\square$ Degradation rate of atrazine(\%) $\rightarrow$ OD600

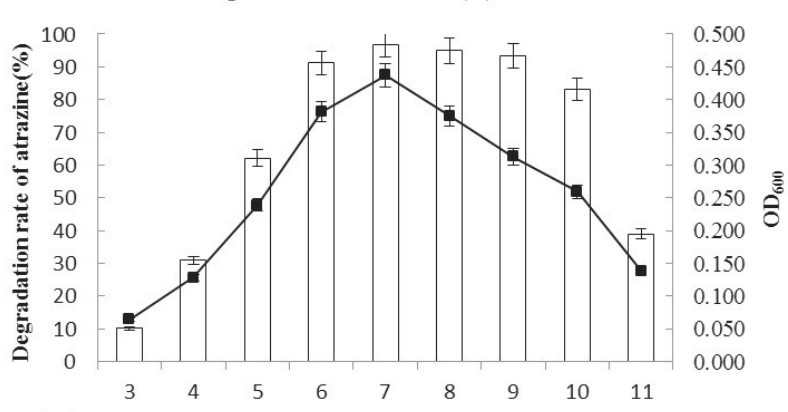

e)

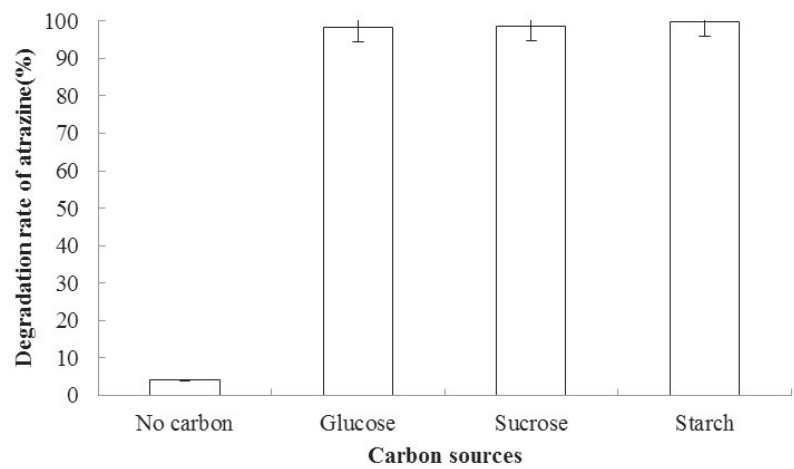

g)

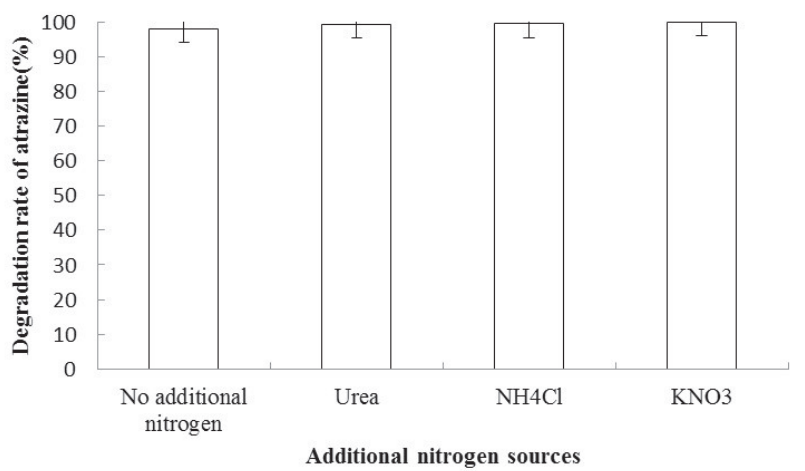

b) $\square$ Degradation rate of atrazine(\%) $\rightarrow$ OD600

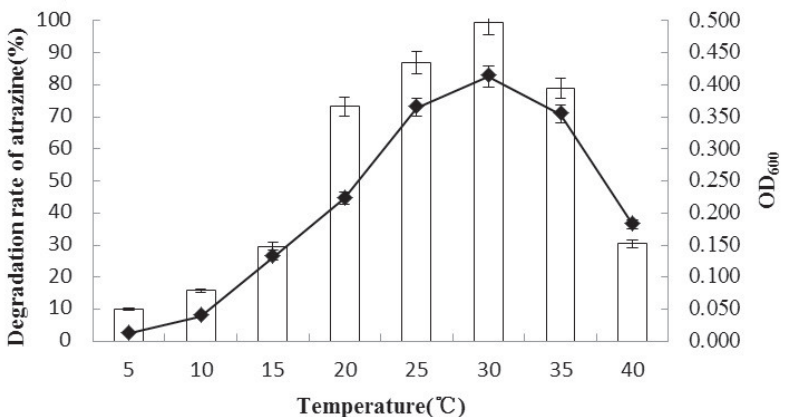

d)

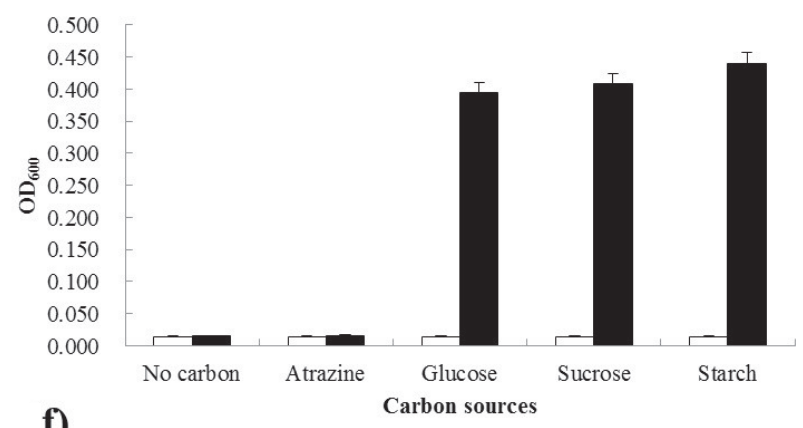

f)

$\square \mathrm{OD} 600(0 \mathrm{~h}) \quad \mathbf{O D} 600(48 \mathrm{~h})$

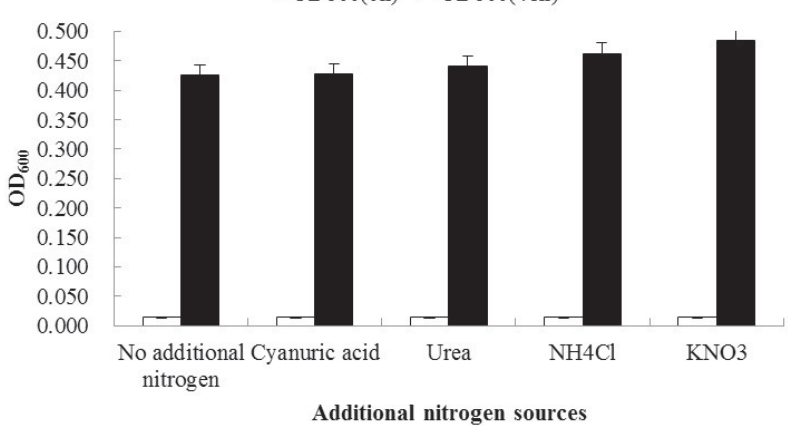

Fig. 4. After 48-h incubation: a) Effects of atrazine concentration on growth and degradation capacity of strain LY-1, b) effects of temperature on the growth and the degradation capacity of strain LY-1, c) effects of $\mathrm{pH}$ on the growth and the degradation capacity of strain LY-1, d) effects of different carbon sources on the growth of strain LY-1, e) effects of different carbon sources on the degradation capacity of strain LY-1, f) effects of different additional nitrogen sources on the growth of strain LY-1, and g) effects of different additional nitrogen sources on the degradation capacity of strain LY-1. 
At 44-48 h, atrazine was almost completely degraded and the concentration of cyanuric acid was also stable. All of these certified that Arthrobacter sp. LY-1 could convert atrazine to cyanuric acid. The speculative pathway of atrazine degradation by Arthrobacter sp. LY-1 was the same as the reported pathway [23].

\section{Effects of Environmental Factors on Growth and Biodegradation}

Atrazine concentration, temperature, $\mathrm{pH}$, carbon, and nitrogen sources influence atrazine degradation, but few reported studies have investigated the effects of these conditions on atrazine degradation. Most the previous studies referred to the degradation of atrazine at lower concentrations. Arthrobacter sp. C3 could almost completely degrade atrazine (25 $\mathrm{mg} \cdot \mathrm{l}^{-1}$ ) after being cultured for $30 \mathrm{~h}$ and Arthrobacter species DNS10 could degrade $99.6 \%$ of $100 \mathrm{mg} \cdot \mathrm{l}^{-1}$ of atrazine within $36 \mathrm{~h}$ [24-25]. Fig. 4 indicated that when the atrazine concentration was below $200 \mathrm{mg} \cdot \mathrm{l}^{-1}$, the degradation rate of atrazine in the medium was more than $90 \%$ within $48 \mathrm{~h}$. When atrazine concentration was $500 \mathrm{mg} \cdot \mathrm{l}^{-1}$, the degradation rate was $50 \%$. This showed that the strain demonstrated a positive degradation effect, although the atrazine concentration was higher. When the atrazine concentration was $100 \mathrm{mg} \cdot \mathrm{l}^{-1}$, the growth and degradation abilities of strain LY-1 were optimal. When the atrazine concentration was $1000 \mathrm{mg} \cdot \mathrm{l}^{-1}$, the growth and degradation abilities of strain LY-1 were less effective. Atrazine has a toxic effect on microorganisms, and if the concentration of atrazine in the culture is too high, then its toxicity will inhibit the metabolic activities of microorganisms, resulting in a significant reduction in growth and degradation activity.

The currently known optimum temperature range for degradation of atrazine by Arthrobacter species HB-5 is $20-40^{\circ} \mathrm{C}$ [26]. The effects of different temperatures on growth and atrazine degradation by Arthrobacter species LY-1 were shown in Fig. 4b), which indicated that the optimum temperature range was $20-35^{\circ} \mathrm{C}$. Growth and degradation abilities were both inhibited when the temperature was higher than $35^{\circ} \mathrm{C}$ or lower than $20^{\circ} \mathrm{C}$. Fig. $4 \mathrm{~b}$ also demonstrated that strain LY-1 exhibited a particular degradation ability at low temperatures, and the degradation rate of atrazine was about $30 \%$ at $15^{\circ} \mathrm{C}$. Therefore, strain LY-1 was also suitable for bioremediation of atrazine at lower temperatures.

The optimum $\mathrm{pH}$ range for atrazine degradation by Pseudomonas sp. ZXY-1 was 6.0-8.0 and Arthrobacter species HB-5 was 6.0-9.0 [27]. The effects of different $\mathrm{pH}$ values on the growth of Arthrobacter species LY-1 and its atrazine degradation ability were shown in Fig. $4 \mathrm{c}$ ). The optimum $\mathrm{pH}$ range was $6.0-10.0$ and the degradation and growth abilities of the strain under alkaline conditions were better than those in acidic conditions. The strain still could have degradation rates of $62.1 \%$ and $38.9 \%$ at $\mathrm{pH} 5.0$ and 11.0 , respectively.
These results indicated that strain LY-1 had wide ranges of temperature and $\mathrm{pH}$, and it demonstrated better environmental adaptability and scavenging ability in contaminated soil. Overall, the strain had superior bioremediation potential.

Carbon sources were a necessary precondition for the growth of strain LY-1. Fig. 4d) indicated that starch was the most suitable carbon source for its growth. When glucose, sucrose, and starch were used as carbon sources, the removal rates of atrazine were more than 95\%; however, when no carbon source was added, the concentration of atrazine changed insignificantly (Fig. 4e). Moreover, when atrazine was used as the sole carbon source, the strain hardly grew. All these findings point to the fact that atrazine could not be used as the sole carbon source of strain LY-1.

Fig. 4f) demonstrated the effects of additional nitrogen sources on the growth of strain LY-1. The addition of urea, ammonium salt, and nitrate promoted the growth of the strain LY-1, with nitrate resulting in the highest strain growth, while cyanuric acid did not cause higher growth. These results implied that strain LY-1 could not use cyanuric acid as a nitrogen source to grow. This also indirectly verified that the strain could convert atrazine to cyanuric acid, but it was unable to degrade cyanuric acid. Some previous studies showed that additional nitrogen sources had a negative impact on atrazine degradation [28-30]. While additional nitrogen sources did not affect the degradation of atrazine by strain LY-1 (Fig. 4g), the degradation rates all exceeded $98 \%$. This illustrated that strain LY-1 had a great potential for bioremediation of atrazine-contaminated soil, and even contaminated soil containing rich nitrogen sources.

\section{Bioremediation Effect of Atrazine-Contaminated Soil by Strain LY-1}

The degradation rate of atrazine in the soil by strain LY-1 was shown in Fig. 5. After incubation at $25^{\circ} \mathrm{C}$ for

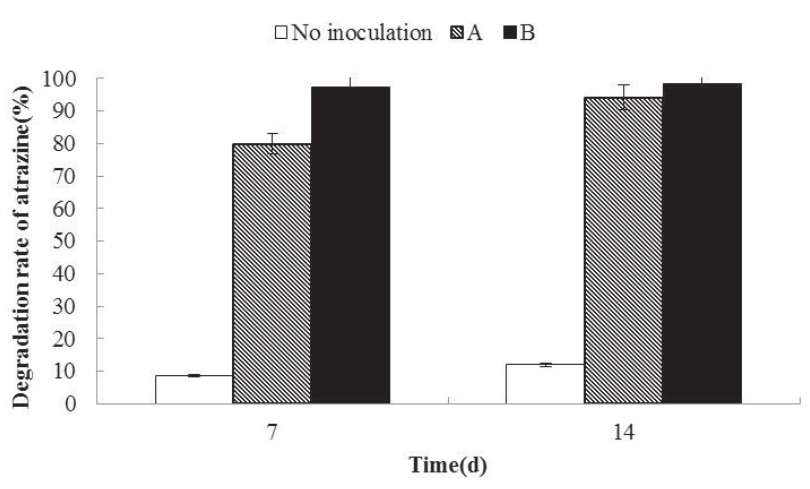

Fig. 5. The degradation rate of atrazine in the soil by strain LY-1 after incubation at $25^{\circ} \mathrm{C}$ for $7 \mathrm{~d}$ and $14 \mathrm{~d}$ : A) strain LY-1 was resuspended with sterile water to a density of about $1 \times 10^{6}$ colony forming units (CFU) $\mathrm{ml}^{-1}$ and B) strain LY-1 was resuspended with sterile water to a density of about $1 \times 10^{8} \mathrm{CFU} \cdot \mathrm{ml}^{-1}$. 
$7 \mathrm{~d}, 79.9 \%$ and $97.4 \%$ of atrazine were removed by $1 \times 10^{6} \mathrm{CFU} \cdot \mathrm{ml}^{-1}$ and $1 \times 10^{8} \mathrm{CFU} \cdot \mathrm{ml}^{-1}$ of LY-1, respectively. After incubation at $25^{\circ} \mathrm{C}$ for $14 \mathrm{~d}$, the degradation rates of atrazine by $1 \times 10^{6} \mathrm{CFU} \cdot \mathrm{ml}^{-1}$ and $1 \times 10^{8} \mathrm{CFU} \cdot \mathrm{ml}^{-1}$ of LY-1 were $94.1 \%$ and $98.3 \%$, respectively. However, after incubation at $25^{\circ} \mathrm{C}$ for $7 \mathrm{~d}$ and $14 \mathrm{~d}, 8.7 \%$ and $12 \%$ of atrazine were removed in the negative control. In comparison, after 20 days, atrazine degradation rates by Arthrobacter sp. DNS10 were $67.7 \%$, and the initial concentration of atrazine in the soil was $20 \mathrm{mg} \cdot \mathrm{kg}^{-1}$. The study showed that atrazinedegrading bacteria Arthrobacter sp. LY-1 had a better remediation capability for atrazine-contaminated soil compared with most other reported atrazine-degrading strains. This strain could achieve a better degradation effect in a relatively short time and might be a new candidate for the remediation of atrazine-contaminated soil.

\section{Conclusions}

A highly efficient atrazine-degrading bacterial strain, Arthrobacter sp. LY-1, was isolated from agricultural soil. The strain harbored $\operatorname{trz} N, \operatorname{atz} B$, and $a t z C$ genes, which could transform atrazine to cyanuric acid. The strain was capable of using atrazine as the sole nitrogen source to grow, while atrazine could not be used as a carbon source for growth. The degradation rates of atrazine under different environmental factors were determined and when atrazine concentration was $100 \mathrm{mg} \cdot \mathrm{l}^{-1}$, the growth and degradation ability of strain LY-1 were the best. The optimum temperature range of this strain was $20-35^{\circ} \mathrm{C}$, and the optimum $\mathrm{pH}$ range was 6.0-10.0. Starch was the most suitable carbon source for its growth and atrazine degradation. Additional nitrogen sources did not affect the degradation of atrazine. Strain LY-1 could degrade $99.5 \%$ of atrazine $\left(100 \mathrm{mg} \cdot \mathrm{l}^{-1}\right)$ in the medium within $48 \mathrm{~h}$, and in the soil, atrazine $\left(100 \mathrm{mg} \cdot \mathrm{kg}^{-1}\right)$ was almost completely degraded by the strain after 14 days. These results demonstrated that strain LY-1 held promising potential for bioremediation of atrazine-contaminated soil.

\section{Acknowledgements}

This study was supported by the Heilongjiang Provincial National Science Foundation (C2016025), and the open fund of State Key Laboratory of Biology for Plant Diseases and Insect Pests (SKLOF201705).

\section{Conflict of Interest}

The authors declare that they have no conflict of interest.

\section{References}

1. MA L.M., CHEN S.S., YUAN J., YANG P.P., LIU Y., STEWART K. Rapid biodegradation of atrazine by Ensifer, sp. strain and its degradation genes. International Biodeterioration \& Biodegradation, 116, 133, 2017.

2. WANG Q., XIE S. Isolation and characterization of a highefficiency soil atrazine-degrading Arthrobacter sp. strain. International Biodeterioration \& Biodegradation, 71 (4), 61, 2012.

3. SHENOY K. Environmentally realistic exposure to the herbicide atrazine alters some sexually selected traits in male guppies. Plos One, 7 (2), e30611, 2012.

4. YE J.Y., ZHANG J.B., GAO J.G., LI H.T., LIANG D., LIU R.M. Isolation and characterization of atrazine-degrading strain Shewanella sp. YJY4 from cornfield soil. Letters in Applied Microbiology, 63 (1), 45, 2016.

5. SAJJAPHAN K., SHAPIR N., WACKETT L.P., PALMER M., BLACKMON B., TOMKINS J., SADOWSKY M.J. Arthrobacter aurescens TC1 atrazine catabolism genes $\operatorname{trz} N, \operatorname{atz} B$, and $\operatorname{atz} C$ are linked on a 160-kilobase region and are functional in Escherichia coli. Applied \& Environmental Microbiology, 70 (7), 4402, 2004.

6. DESITTI C., CHERUTI U., BELIAVSKI M., TARRE S., GREEN M. Long-term atrazine degradation with microtube-encapsulated Pseudomonas sp. strain ADP. Environmental Engineering Science, 33 (3), 2016.

7. YANG X., WEI H., ZHU C., GENG B. Biodegradation of atrazine by the novel Citricoccus sp. strain TT3. Ecotoxicology \& Environmental Safety, 147, 144, 2017.

8. KOLEKAR P.D., PHUGARE S.S., JADHAV J.P. Biodegradation of atrazine by Rhodococcus sp. $\mathrm{BCH} 2$ to $\mathrm{N}$-isopropylammelide with subsequent assessment of toxicity of biodegraded metabolites. Environmental Science \& Pollution Research, 21 (3), 2334, 2014.

9. WANG J., ZHU L., WANG Q., WANG J., XIE H. Isolation and characterization of atrazine mineralizing bacillus subtilis strain HB-6. Plos One, 9 (9), e107270, 2014.

10. GOVANTES F., GARCIAGONZALEZ V., PORRUA O., PLATERO A.I., JIMENEZFERNANDEZ A., SANTERO E. Regulation of the atrazine-degradative genes in Pseudomonas sp. strain ADP. Fems Microbiology Letters, 310 (1), 1, 2010.

11. MEYER A.H., PENNING H., ELSNER M. C and N isotope fractionation suggests similar mechanisms of microbial atrazine transformation despite involvement of different enzymes ( $A t z A$ and $\operatorname{Tr} z N$ ). Environmental Science \& Technology, 43 (21), 8079, 2009.

12. KONG X., JIANG J., MA J., YANG Y., LIU W., LIU Y. Degradation of atrazine by UV/chlorine: efficiency, influencing factors, and products. Water Research, 90, 15, 2016.

13. FRANK J.A., REICH C.I., SHARMA S., WEISBAUM J.S., WILSON B.A., OLSEN G.J. Critical evaluation of two primers commonly used for amplification of bacterial 16S rRNA genes. Applied \& Environmental Microbiology, 74 (8), 2461, 2008.

14. ZHANG Y., JIANG Z., CAO B., HU M., WANG Z.G., DONG X.N. Metabolic ability and gene characteristics of Arthrobacter sp strain DNS10, the sole atrazinedegrading strain in a consortium isolated from black soil. International Biodeterioration \& Biodegradation, 65 (8), 1140, 2011.

15. WANG Q., XIE S. Isolation and characterization of a highefficiency soil atrazine-degrading Arthrobacter sp. strain. 
International Biodeterioration \& Biodegradation, 71 (4), 61, 2012.

16. DOUGLASS J.F., RADOSEVICH M., TUOVINEN O.H. Molecular analysis of atrazine-degrading bacteria and catabolic genes in the water column and sediment of a created wetland in an agricultural/urban watershed. Ecological Engineering, 83, 405, 2015.

17. VACLAVIK L., ROSMUS J., POPPING B., HAJSLOVA $\mathrm{J}$. Rapid determination of melamine and cyanuric acid in milk powder using direct analysis in real time-time-offlight mass spectrometry. Journal of Chromatography A, 1217 (25), 4204, 2010.

18. TOPP E. A comparison of three atrazine-degrading bacteria for soil bioremediation. Biology \& Fertility of Soils, 33 (6), 529, 2001.

19. GUO Q., ZHANG J., WAN R., XIE S. Impacts of carbon sources on simazine biodegradation by Arthrobacter strain SD3-25 in liquid culture and soil microcosm. International Biodeterioration \& Biodegradation, 89 (4), 1, 2014.

20. WANG Q., XIE S., HU R. Bioaugmentation with Arthrobacter sp. strain DAT1 for remediation of heavily atrazine-contaminated soil. International Biodeterioration \& Biodegradation, 77 (77), 63, 2013.

21. SAJARKAR S., BHARDWAJ P., STORCK V., DEVERSLAMRANI M., MARTIN-LAURENT F., KAPLEY A. S-triazine degrading bacterial isolate Arthrobacter sp. AK-YN10, a candidate for bioaugmentation of atrazine contaminated soil. Applied Microbiology \& Biotechnology, 100 (2), 903, 2016.

22. MONGODIN E.F., SHAPIR N., DAUGHERTY S.C., DEBOY R.T., EMERSON J.B., SHVARTZBEYN A., RADUNE D., VAMATHEVAN J., RIGGS F., GRINBERG V., KHOURI H., WANKETT L.P., NELSON K.E., SADOWSKY M.J. Secrets of soil survival revealed by the genome sequence of Arthrobacter aurescens TC1. Plos Genetics, 2 (12), e214, 2006.
23. ZHANG Y., CAO B., JIANG Z., DONG X.N., HU M., WANG Z.G. Metabolic ability and individual characteristics of an atrazine-degrading consortium DNC5. Journal of Hazardous Materials, 237-238 (17), 376, 2012.

24. WANG H., LIU Y., LI J., LIN M., HU X. Biodegradation of atrazine by Arthrobacter sp. C3, isolated from the herbicide-contaminated corn field. International Journal of Environmental Science \& Technology, 13 (1), 257, 2016.

25. ZHANG Y., ZHANG Q.Y., NAN C., GE S.J., JIANG Z., HU M., CAO B. Biodegradation of atrazine by free and immobilized cells of Arthrobacter sp. strain DNS10. Environmental Engineering \& Management Journal, 14 (4), 819, 2015.

26. WANG J.H., ZHU L.S., LIU A.J., MA T.T., WANG Q., XIE H., WANG J., JIANG T., ZHAO R.S. Isolation and characterization of an Arthrobacter sp. strain HB-5 that transforms atrazine. Environmental Geochemistry \& Health, 33 (3), 259, 2011.

27. ZHAO X., WANG L., MA F., BAI S., YANG J., QI S. Pseudomonas sp. ZXY-1, a newly isolated and highly efficient atrazine-degrading bacterium, and optimization of biodegradation using response surface methodology. Journal of Environmental Science, 54 (4), 152, 2017.

28. GARCIA-GONZALEZ V., GOVANTES F., SHAW L.J., BURNS R.G., SANTERO E. Nitrogen control of atrazine utilization in Pseudomonas sp. strain ADP. Applied \& Environmental Microbiology, 69 (12), 6987, 2003.

29. GUILLEN GARCES R.A., HANSEN A.M., VAN A.M. Mineralization of atrazine in agricultural soil: inhibition by nitrogen. Environmental Toxicology \& Chemistry, 26 (5), 844, 2007.

30. ROBERTM Z., LJASON K., MARKA W., CESARE A., KRISHNAN R. Glufosinate and ammonium sulfate inhibit atrazine degradation in adapted soils. Biology \& Fertility of Soils, 45 (1), 19, 2008. 
